\title{
Optimization of thermostable amylopullulanase production in solid state fermentation by Clostridium thermosulfurogenes SVM17 through Plackett-Burman and response surface methodological approaches
}

\author{
Mrudula. S. \\ Department of Microbiology, M. G. R College, Dr. M. G. R. Nagar, Hosur,- 635 109,Tamil Nadu, India. \\ E-mail: somamrudula@hotmail.com \\ Received 7 December 2009; received in revised form 16 February 2010; accepted 28 February 2010
}

\begin{abstract}
A total of fifteen nutrients comprising five carbon sources, four complex organic sources and three each of nitrogen and trace mineral sources were screened in a total of sixteen experiments using Plackett-Burman design for production of thermostable amylopullulanase by Clostridium thermosulfurogenes SVM17 in solid state fermentation (SSF) system. The design comprises screening of ' $n-1$ ' variables in ' $n$ ' number of experiments. Yield of enzyme was statistically analyzed to obtain for regression coefficients and $t$-values. Among fifteen nutrients screened, based on their effect in terms of product promoting ability, maltose, bajra flour, peptone, $\mathrm{CaCl}_{2} \cdot \mathrm{H}_{2} \mathrm{O}$ and $\mathrm{MnCl}_{2} \cdot 4 \mathrm{H}_{2} \mathrm{O}$ were considered promising nutrients for enzyme production and selected for optimization of their concentration using response surface methodology based on the central composite rotatable design (CCRD). The design comprises a total of 54 experimental trials with first 32 organized in a fractional factorial design and experimental trials from 33-40 and 51-54 involving the replication of central points. The experimental trials from $41-50$ are called star points or axial points. The design was applied to determine the effects of above medium components and their mutual interactions on amylopullulanase production. Within the tested range of concentrations, except $\mathrm{CaCl}_{2} \cdot 2 \mathrm{H}_{2} \mathrm{O}$, all other components had significant effect on enzyme production. The optimum level of medium components for maximum production of the enzyme was (\% w/w): maltose, 22.0; peptone, 0.8; $\mathrm{MnCl}_{2} \cdot 4 \mathrm{H}_{2} \mathrm{O}, 50 \mathrm{ppm} ; \mathrm{CaCl}_{2} \cdot 2 \mathrm{H}_{2} \mathrm{O}, 15 \mathrm{ppm}$ and bajra flour, 11.0.
\end{abstract}

Keywords: Clostridium thermosulfurogenes, amylopullulanase, solid state fermentation, Plackett-Burman design, response surface methodology

\section{INTRODUCTION}

Bioprocessing of starch into maltose and maltooligosaccharides by enzymatic means is gaining importance, because of their potential use in food, pharmaceutical, beverage and fine chemical industries (Fogarty and Kelly, 1990; Saha et al., 2009). So far reported amylases are thermally unstable and expensive (Hyun and Zeikus, 1985; Shen et al., 1988). Therefore a high value is placed on extreme thermostable and thermoactive amylases in bioprocessing of starch, since the bioprocessing of starch at elevated temperature improves the solubility of starch, decreases its viscosity, limits microbial contamination, reduces reaction times and more economical (Brown and Kelly, 1993). It is considered advantageous to have microorganisms that produce thermostable enzyme having properties of both amylase and pullulanase, because it cleaves both $\alpha-1,4$ and $\alpha-1,6$ linkages, respectively (Melasniemi, 1987; Spreinat and Antranikian, 1990; Dong et al., 1997; Ganghofner et al., 1998; Duffner, 2000; Gomes et al., 2003; Vishnu et al., 2006; Kim et al., 2008; Zareian et al., 2010). Therefore such type of endo acting enzymes have potential application for enhancement of starch saccharification process in industry (Ramesh et al., 1994).
Thermoanaerobes show promise for the production of thermostable enzymes (Zeikus, 1979).

In this direction, anaerobic and thermophilic bacteria that secrete amylases were isolated in our laboratory (Swamy and Seenayya, 1996a). These strains were screened for production of amylolytic enzymes. The strain Clostridium thermosulfurogenes SVM17, which produced higher yield of the enzyme having properties of both amylase and pullulanase and stable at $100{ }^{\circ} \mathrm{C}$ was selected. Recently, the bacterial systems were investigated for production of enzymes and metabolites by solid state fermentation (SSF). These fermentation systems were considered to be closer to the natural habitats of microorganisms (Archana and Satyanarayana, 1997). The SSF has many advantages over submerged fermentation (SmF), including no need for complex machinery and sophisticated control systems; less volume of liquid required for product recovery, which could reduce the cost of downstream processing and subsequent waste treatment; usage of simple and cheap media for fermentation; lower energy demand, and often a high product yield; lower risk of contamination due to the inability of most contaminants to grow in absence of free flowing water (Ramesh and Lonsane, 1990; Pandey, 1992 
Gessesse and Mamo, 1999). Therefore the SSF process is considered to be more economical.

Selection of nutrients such as carbon, nitrogen and other nutrients is one of the most critical stages in an efficient and economic process development. The methodologies used for screening the nutrients fall into two categories; classical and statistical (Greasham, 1983). The application of statistical methodologies in fermentation process development has numerous advantages in terms of rapid and reliable short listing of nutrients, understanding the interactions among nutrients at varying concentrations and tremendous reduction in total number of experiments resulting in less time consumption, glassware, chemicals and man power (Srinivas et al., 1994; Rama Mohan Reddy et al., 1999a; Chauhan et al., 2007; Reddy et al., 2008). PlackettBurman design (Plackett and Burman, 1946) is a two level fractional factorial design and allows screening of up to ' $n-1$ ' variables in just ' $n$ ' number of experiments. In this design, generally a multiple of four i.e., 4, 8, 12, 16, $20, \ldots, 4 \mathrm{n}$ experiments are required to screen $3,7,11,15$ $19, \ldots ., 4 n-1$ components respectively, where ' $n$ ' is an integer. This design is employed for production of various metabolites and enzymes in submerged (Chauhan et al., 2007; Yu et al., 1997; Son et al., 1998; Khanna and Srivastava, 2005) and solid state fermentation (Srinivas et al., 1994; Rama Mohan Reddy et al., 1999a ; Ramana Murthy, 1994; Ramana Murthy et al., 1999; Cockshott and Sullivan Gary, 2001; Md Altaf et al., 2006).
Yield of any microbial product can be improved by optimization of medium components that are required in fermentation processes. Application of statistical methodologies in fermentation process development can result in improved yield of the product, reduced process variability, closer confirmation of the output response (product yield/ productivity) to normal and target requirements, reduced development time with overall costs. Conventional practice of single variable optimization is by maintaining other variables involved at a constant level. The major disadvantage of this 'changesingle-factor-at-a-time' method is that it does not include interactive effects among the variables (Oh et al., 1995; Sen and Swaminathan, 1997; Satyanarayana et al., 1999; Jaganatha Rao et al., 2000). This method is a time consuming process and requires a number of experiments to determine optimum level, which are unreliable and therefore considered to be inferior to statistical methodologies. These limitations of a single factor optimization process can be eliminated by optimizing all the affecting parameters collectively by statistical experimental design using response surface methodology (RSM) (Box and Wilson, 1957; Khuri and Cornell, 1987; Jagannadha Rao, et al., 2000).

Today literature provides less information on the production of thermostable amylopullulanase in SSF. In the present study, we report the screening of nutrients using Plackett-Burman design and optimization of their concentration using response surface methodology

Table 1: Plackett-Burman design of experiment for screening of fifteen medium components for the production of thermostable amylopullulanase by Clostridium thermosulfurogenes SVM17 in solid state fermentation

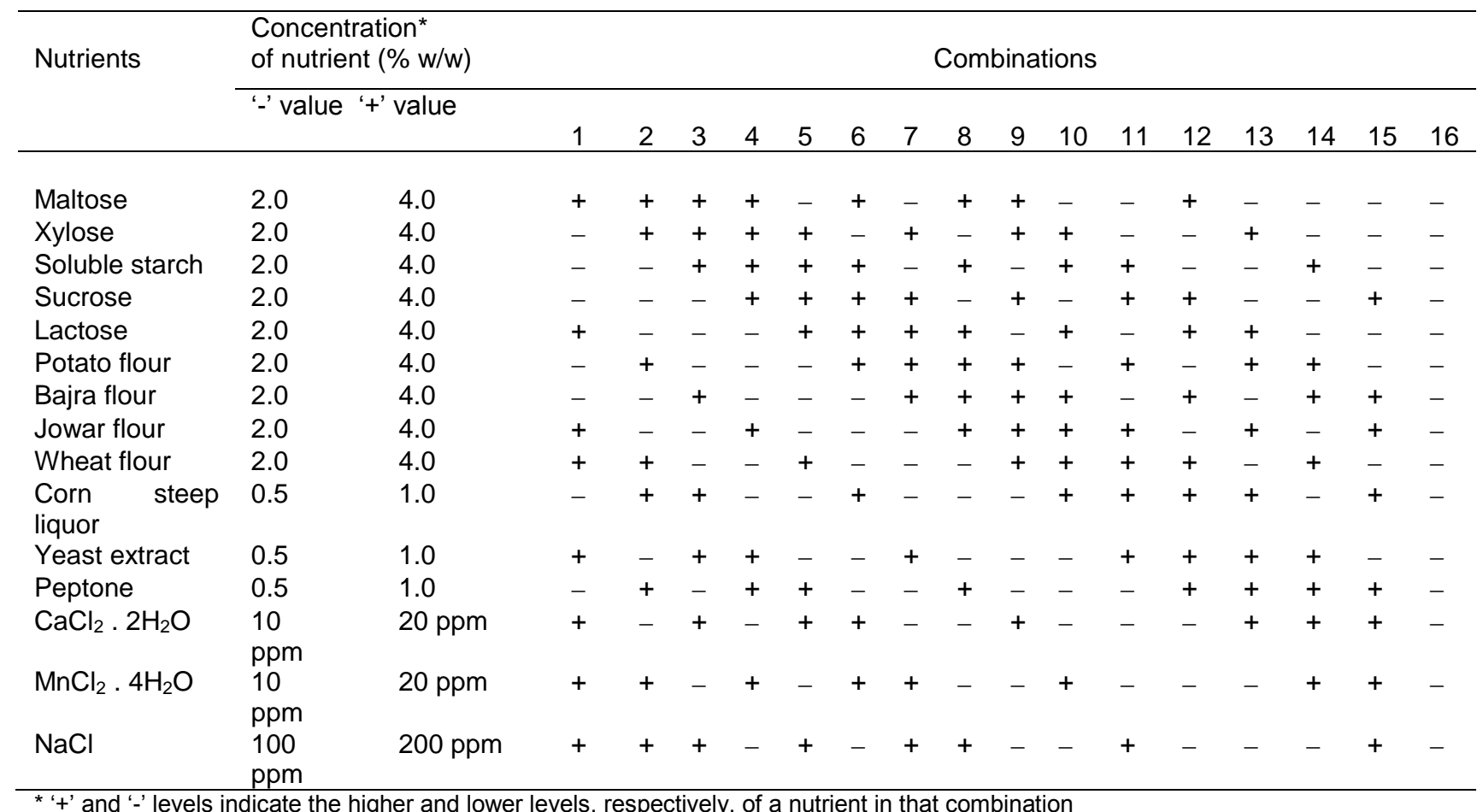


Table 2: Yields of thermostable amylase and pullulanase by $C$. thermosulfurogenes SVM17 obtained in screening of fifteen nutrients using Plackett-Burman design in solid state fermentation

\begin{tabular}{ccccc}
\hline Combination number & \multicolumn{2}{c}{ Amylase activity (U/kg BB) } & \multicolumn{2}{c}{ Pullulanase activity (U/kg BB) } \\
\cline { 2 - 4 } & Expt I & Expt II & Expt I & 26,241 \\
\hline 1 & 17,071 & 16,547 & 24,698 & 27,332 \\
2 & 17,930 & 16,983 & 26,410 & 25,919 \\
3 & 17,452 & 17,669 & 26,389 & 27,049 \\
4 & 17,693 & 16,701 & 25,893 & 24,161 \\
5 & 15,937 & 15,220 & 28,158 \\
6 & 18,398 & 17,757 & 23,897 & 28,409 \\
7 & 18,968 & 18,909 & 27,080 & 26,060 \\
8 & 17,829 & 17,542 & 28,442 & 26,967 \\
9 & 17,071 & 16,972 & 26,417 & 25,298 \\
10 & 16,692 & 16,043 & 25,922 & 21,387 \\
11 & 14,036 & 14,152 & 24,588 & 26,684 \\
13 & 15,933 & 15,532 & 20,486 & 21,157 \\
14 & 14,605 & 14,830 & 26,293 & 22,425 \\
15 & 14,984 & 15,649 & 21,779 & 19,686 \\
& 13,277 & 13,118 & 19,856 & 21,502 \\
\hline
\end{tabular}

Experiments were conducted in duplicates as per the design in $120 \mathrm{~mL}$ anaerobic serum vials containing $10 \mathrm{~g}$ of wheat bran with respective concentrations of nutrients (as shown in Table 1) dissolves in distilled water incubated at $60{ }^{\circ} \mathrm{C}$ for $72 \mathrm{~h}$. The enzyme activities were assayed under standard conditions

Table 3: Regression coefficients and t-values obtained from the yields of amylase and pullulanase in the screening experiments in solid state fermentation

\begin{tabular}{lcccc}
\hline Nutrients & \multicolumn{2}{c}{ Amylase } & \multicolumn{2}{c}{ Pullulanase } \\
\cline { 2 - 5 } & Reg. coeff & $t$-value & Reg. coeff & t-value \\
\hline INTERCEPT & 16242.00 & 287.19 & 24710.00 & 263.43 \\
Maltose & 946.00 & 16.73 & 1760.00 & 18.75 \\
Xylose & 608.00 & 10.76 & 930.00 & 9.92 \\
Soluble starch & 238.00 & 4.22 & 130.00 & 1.33 \\
Sucrose & -16.00 & -0.29 & 310.00 & 3.34 \\
Lactose & 495.00 & 8.77 & 9.76 \\
Potato flour & 421.00 & 7.44 & 915.00 & 3.91 \\
Bajra flour & 235.00 & 4.16 & 366.00 & 4.09 \\
Jowar flour & -359.00 & -6.36 & -702.00 & -7.49 \\
Wheat flour & -195.00 & -3.46 & -26.00 & -0.28 \\
Corn steep liquor & -342.00 & -6.05 & -388.00 & -4.14 \\
Yeast extract & 50.00 & 0.88 & 43.00 & 0.46 \\
Peptone & -386.00 & -6.82 & -466.00 & -4.97 \\
CaCl $2 \cdot 2 \mathrm{H}_{2} \mathrm{O}$ & -208.00 & -3.67 & -514.00 & -5.48 \\
$\mathrm{MnCl}_{2} \cdot 4 \mathrm{H}_{2} \mathrm{O}$ & 423.00 & 7.49 & 522.00 & 5.57 \\
$\mathrm{NaCl}^{\mathrm{N}}$ & 173.00 & 3.05 & 26.00 & 0.28 \\
\hline
\end{tabular}

Regression coefficients and t-values were obtained by subjecting the enzyme yields (Table 2) to statistical analysis using 'Indostat' statistical software

for production of thermostable amylopullulanase by Clostridium thermosulfurogenes SVM17 in SSF.

\section{MATERIALS AND METHODS}

\section{Microorganism}

The bacterial strain used in the present study was isolated in our laboratory (Swamy and Seenayya, 1996a) and identified as Clostridium thermosulfurogenes SVM17.

\section{Solid state fermentation technique}

Solid state fermentation was carried out in $120 \mathrm{~mL}$ serum vials that contained $10 \mathrm{~g}$ of wheat bran moistened with appropriate volume of distilled water containing the required concentration of nutrients. The medium was flushed with nitrogen gas to create anaerobic conditions and vials were sealed and sterilized at $121^{\circ} \mathrm{C}$ for $15 \mathrm{~min}$. After cooling to room temperature $\left(28 \pm 2{ }^{\circ} \mathrm{C}\right)$, a $2 \%(\mathrm{v} / \mathrm{w})$ of $2.5 \%(\mathrm{w} / \mathrm{v}) \mathrm{Na}_{2} \mathrm{~S}$ solution was added to maintain further 
Table 4: Central composite rotatable design (CCRD) of five medium components in coded and uncoded units: Effect of each combination on the production of thermostable amylopullulanase by $C$. thermosulfurogenes SVM17 in SSF

\begin{tabular}{|c|c|c|c|c|c|}
\hline $\begin{array}{l}\text { Combination } \\
\text { number }\end{array}$ & $\begin{array}{l}\text { Maltose } \\
\%(w / w) \\
X_{1}\end{array}$ & $\begin{array}{l}\text { Peptone } \\
\%(w / w) \\
\mathrm{X}_{2}\end{array}$ & $\begin{array}{l}\mathrm{MnCl}_{2} \cdot 4 \mathrm{H}_{2} \mathrm{O} \\
\mathrm{ppm} \\
\mathrm{X}_{3}\end{array}$ & $\begin{array}{l}\mathrm{CaCl}_{2} \cdot 2 \mathrm{H}_{2} \mathrm{O} \\
\mathrm{ppm} \\
\mathrm{X}_{4}\end{array}$ & $\begin{array}{l}\text { Bajra flour } \\
\%(w / w) \\
X_{5}\end{array}$ \\
\hline 1 & $-1(7.0)$ & $-1(0.6)$ & $-1(30.0)$ & $-1(10.0)$ & $-1(7.0)$ \\
\hline 2 & $1(17.0)$ & $-1(0.6)$ & $-1(30.0)$ & $-1(10.0)$ & $-1(7.0)$ \\
\hline 3 & $-1(7.0)$ & $1(1.0)$ & $-1(30.0)$ & $-1(10.0)$ & $-1(7.0)$ \\
\hline 4 & $1(17.0)$ & $1(1.0)$ & $-1(30.0)$ & $-1(10.0)$ & $-1(7.0)$ \\
\hline 5 & $-1(7.0)$ & $-1(0.6)$ & $1(70.0)$ & $-1(10.0)$ & $-1(7.0)$ \\
\hline 6 & $1(17.0)$ & $-1(0.6)$ & $1(70.0)$ & $-1(10.0)$ & $-1(7.0)$ \\
\hline 7 & $-1(7.0)$ & $1(1.0)$ & $1(70.0)$ & $-1(10.0)$ & $-1(7.0)$ \\
\hline 8 & $1(17.0)$ & $1(1.0)$ & $1(70.0)$ & $-1(10.0)$ & $-1(7.0)$ \\
\hline 9 & $-1(7.0)$ & $-1(0.6)$ & $-1(30.0)$ & $1(20.0)$ & $-1(7.0)$ \\
\hline 10 & $1(17.0)$ & $-1(0.6)$ & $-1(30.0)$ & $1(20.0)$ & $-1(7.0)$ \\
\hline 11 & $-1(7.0)$ & $1(1.0)$ & $-1(30.0)$ & $1(20.0)$ & $-1(7.0)$ \\
\hline 12 & $1(17.0)$ & $1(1.0)$ & $-1(30.0)$ & $1(20.0)$ & $-1(7.0)$ \\
\hline 13 & $-1(7.0)$ & $-1(0.6)$ & $1(70.0)$ & $1(20.0)$ & $-1(7.0)$ \\
\hline 14 & $1(17.0)$ & $-1(0.6)$ & $1(70.0)$ & $1(20.0)$ & $-1(7.0)$ \\
\hline 15 & $-1(7.0)$ & $1(1.0)$ & $1(70.0)$ & $1(20.0)$ & $-1(7.0)$ \\
\hline 16 & $1(17.0)$ & $1(1.0)$ & $1(70.0)$ & $1(20.0)$ & $-1(7.0)$ \\
\hline 17 & $-1(7.0)$ & $-1(0.6)$ & $-1(30.0)$ & $-1(10.0)$ & $1(17.0)$ \\
\hline 18 & $1(17.0)$ & $-1(0.6)$ & $-1(30.0)$ & $-1(10.0)$ & $1(17.0)$ \\
\hline 19 & $-1(7.0)$ & $1(1.0)$ & $-1(30.0)$ & $-1(10.0)$ & $1(17.0)$ \\
\hline 20 & $1(17.0)$ & $1(1.0)$ & $-1(30.0)$ & $-1(10.0)$ & $1(17.0)$ \\
\hline 21 & $-1(7.0)$ & $-1(0.6)$ & $1(70.0)$ & $-1(10.0)$ & $1(17.0)$ \\
\hline 22 & $1(17.0)$ & $-1(0.6)$ & $1(70.0)$ & $-1(10.0)$ & $1(17.0)$ \\
\hline 23 & $-1(7.0)$ & $1(1.0)$ & $1(70.0)$ & $-1(10.0)$ & $1(17.0)$ \\
\hline 24 & $1(17.0)$ & $1(1.0)$ & $1(70.0)$ & $-1(10.0)$ & $1(17.0)$ \\
\hline 25 & $-1(7.0)$ & $-1(0.6)$ & $-1(30.0)$ & $1(20.0)$ & $1(17.0)$ \\
\hline 26 & $1(17.0)$ & $-1(0.6)$ & $-1(30.0)$ & $1(20.0)$ & $1(17.0)$ \\
\hline 27 & $-1(7.0)$ & $1(1.0)$ & $-1(30.0)$ & $1(20.0)$ & $1(17.0)$ \\
\hline 28 & $1(17.0)$ & $1(1.0)$ & $-1(30.0)$ & $1(20.0)$ & $1(17.0)$ \\
\hline 29 & $-1(7.0)$ & $-1(0.6)$ & $1(70.0)$ & $1(20.0)$ & $1(17.0)$ \\
\hline 30 & $1(17.0)$ & $-1(0.6)$ & $1(70.0)$ & $1(20.0)$ & $1(17.0)$ \\
\hline 31 & $-1(7.0)$ & $1(1.0)$ & $1(70.0)$ & $1(20.0)$ & $1(17.0)$ \\
\hline 32 & $1(17.0)$ & $1(1.0)$ & $1(70.0)$ & $1(20.0)$ & $1(17.0)$ \\
\hline 33 & $0(12.0)$ & $0(0.8)$ & $0(50.0)$ & $0(15.0)$ & $0(12.0)$ \\
\hline 34 & $0(12.0)$ & $0(0.8)$ & $0(50.0)$ & $0(15.0)$ & $0(12.0)$ \\
\hline 35 & $0(12.0)$ & $0(0.8)$ & $0(50.0)$ & $0(15.0)$ & $0(12.0)$ \\
\hline 36 & $0(12.0)$ & $0(0.8)$ & $0(50.0)$ & $0(15.0)$ & $0(12.0)$ \\
\hline 37 & $0(12.0)$ & $0(0.8)$ & $0(50.0)$ & $0(15.0)$ & $0(12.0)$ \\
\hline 38 & $0(12.0)$ & $0(0.8)$ & $0(50.0)$ & $0(15.0)$ & $0(12.0)$ \\
\hline 39 & $0(12.0)$ & $0(0.8)$ & $0(50.0)$ & $0(15.0)$ & $0(12.0)$ \\
\hline 40 & $0(12.0)$ & $0(0.8)$ & $0(50.0)$ & $0(15.0)$ & $0(12.0)$ \\
\hline 41 & $-2(2.0)$ & $0(0.8)$ & $0(50.0)$ & $0(15.0)$ & $0(12.0)$ \\
\hline 42 & $2(22.0)$ & $0(0.8)$ & $0(50.0)$ & $0(15.0)$ & $0(12.0)$ \\
\hline 43 & $0(12.0)$ & $-2(0.4)$ & $0(50.0)$ & $0(15.0)$ & $0(12.0)$ \\
\hline 44 & 0 (12.0) & $2(1.2)$ & $0(50.0)$ & $0(15.0)$ & $0(12.0)$ \\
\hline 45 & $0(12.0)$ & $0(0.8)$ & $-2(10.0)$ & $0(15.0)$ & $0(12.0)$ \\
\hline 46 & $0(12.0)$ & $0(0.8)$ & $2(90.0)$ & $0(15.0)$ & $0(12.0)$ \\
\hline 47 & $0(12.0)$ & $0(0.8)$ & $0(50.0)$ & $-2(5.0)$ & $0(12.0)$ \\
\hline 48 & $0(12.0)$ & $0(0.8)$ & $0(50.0)$ & $2(25.0)$ & $0(12.0)$ \\
\hline 49 & $0(12.0)$ & $0(0.8)$ & $0(50.0)$ & $0(15.0)$ & $-2(2.0)$ \\
\hline \multirow[t]{2}{*}{50} & $0(12.0)$ & $0(0.8)$ & $0(50.0)$ & $0(15.0)$ & $2(22.0)$ \\
\hline & & & 184 & & (continued) \\
\hline
\end{tabular}




\begin{tabular}{|c|c|c|c|c|c|}
\hline 51 & $0(12.0)$ & $0(0.8)$ & $0(50.0)$ & $0(15.0)$ & $0(12.0)$ \\
\hline 52 & $0(12.0)$ & $0(0.8)$ & $0(50.0)$ & $0(15.0)$ & $0(12.0)$ \\
\hline 53 & $0(12.0)$ & $0(0.8)$ & $0(50.0)$ & $0(15.0)$ & $0(12.0)$ \\
\hline 54 & $0(12.0)$ & $0(0.8)$ & $0(50.0)$ & $0(15.0)$ & $0(12.0)$ \\
\hline
\end{tabular}

Uncoded units are given in parentheses

reduced conditions followed by $2 \mathrm{~mL}$ of $24 \mathrm{~h}$ old inoculum. Contents in the vials were mixed thoroughly and incubated at $60{ }^{\circ} \mathrm{C}$ in horizontal position. During incubation, the contents in vials were periodically mixed by gentle shaking and accumulated gases were removed using a sterile needle. At the end of incubation time (72 h), vials were taken out and enzyme was extracted from each vial with $0.1 \mathrm{M}$ sodium acetate buffer $(\mathrm{pH} 5.5)$ at $1: 5 \mathrm{w} / \mathrm{v}$ ratio $28 \pm 2{ }^{\circ} \mathrm{C}$ with a contact time of $1 \mathrm{~h}$ at an agitation speed of $150 \mathrm{rpm}$ on a rotary shaker. Extracts were clarified by squeezing through dampened cheese cloth (Ramesh and Lonsane, 1990), followed by centrifugation at $8000 \mathrm{rpm}$ for $20 \mathrm{~min}$ at $4^{\circ} \mathrm{C}$, and the supernatant was used as source of extra cellular enzyme.

\section{Screening of nutrients using Plackett-Burman design}

A total of fifteen nutrients comprising of five carbon source (maltose, xylose, soluble starch, sucrose and lactose), four complex organic source (potato flour, bajra flour, jowar flour and wheat flour) and three each of nitrogen (corn steep liquor, yeast extract and peptone) and trace mineral sources $\left(\mathrm{CaCl}_{2} \cdot 2 \mathrm{H}_{2} \mathrm{O}, \mathrm{MnCl}_{2} \cdot 4 \mathrm{H}_{2} \mathrm{O}\right.$ and $\left.\mathrm{NaCl}\right)$ were screened in a total of sixteen experiments using Plackett-Burman design (Table 1).

Concentration for each nutrient was fixed based on the literature and on our own experience gained (Rama Mohan Reddy et al., 1999). All nutrients except monosaccharide, disaccharides and corn steep liquor were dissolved in appropriate amount of distilled water (moistening agent), $\mathrm{pH}$ was adjusted to 7.5 and then used for moistening the wheat bran before sterilization. Monosaccharide, disaccharide sugars and corn steep liquor were prepared at a concentration of $10 \mathrm{X}$ solutions and sterilized separately by autoclaving at 10 psi for 10 min and required concentration was added to the medium before inoculation. Care was taken to maintain the moisture level of inoculated medium at $73 \%$. The data on the yields of amylase and pullulanase in these sixteen experiments were subjected to compatible analysis (Plackett and Burman, 1946) to obtain regression coefficients and $t$-values. The 'Indostat' statistical package was used for the data analysis. The nutrients with highest $t$-values were considered as the best nutrients and thus selected for further optimization studies (Rama Mohan Reddy et al., 1999b)

\section{Optimization of concentration of nutrients using RSM}

A central composite rotatable design (CCRD) was used to optimize the concentrations of nutrients. The design contains a total of 54 experimental trials with first 32 organized in a fractional factorial design (Cochran and
Cox, 1957), the experimental trials from 33-40 and 51-54 involve the replications of central points and experimental trials from 41-50 are axial points (star points). The response i.e., amount of enzyme produced by $C$. thermosulfurogenes SVM17 was assumed to be influenced by the five factors selected for the study. Once the experiments were performed, the coefficients of second-order polynomial model for five factors were calculated from the following equation (Montgomery, 1991).

$Y=b_{0}+b_{1} X_{1}+b_{2} X_{2}+b_{3} X_{3}+b_{4} X_{4}+b_{5} X_{5}+b_{11} X_{1}^{2}+b_{22}$ $x_{2}{ }^{2}+b_{33} x_{3}^{2}+b_{44} x_{4}^{2}+b_{55} x_{5}^{2}+b_{12} x_{1} x_{2}+b_{13} x_{1} x_{3}+$ $b_{14} x_{1} x_{4}+b_{15} x_{1} x_{5}+b_{23} x_{2} x_{3}+b_{24} x_{2} X_{4}+b_{25} x_{2} X_{5}+b_{34} x_{3}$ $\mathrm{X}_{4}+\mathrm{b}_{35} \mathrm{X}_{3} \mathrm{X}_{5}+\mathrm{b}_{45} \mathrm{X}_{4} \mathrm{X}_{5}+\mathrm{B}$

Where, $y$ is the response (predicted yield of enzyme), $b_{0}$ is the intercept, $b_{1}, b_{2}, b_{3}, b_{4}$ and $b_{5}$ are the linear coefficients, $b_{11}, b_{22}, b_{33}, b_{44}$ and $b_{55}$ are the quadratic coefficients and $b_{12-15}, b_{23-25}, b_{34-35}$ and $b_{45}$ are the interactive coefficients.

Significance of the model is determined based on lack of fit and significance of each coefficient was determined using the student $t$-test (Gong and Chen, 1998; Rama Mohan Reddy et al., 2000). Graphical representation of these equations are called response surface curves, used to describe the individual and cumulative effect of the test variable (factor) on the response and to determine the mutual interactions between two test variables and their subsequent effect on the response (Khuri and Cornell, 1987; Montgomery, 1991). The three dimensional response surface plot was drawn with vertical axis representing the enzyme yield and two horizontal axes representing five different levels of two explanatory nutrients by keeping other three factors at zero level. The results were analyzed using the 'Indostat' statistical package. Optimum concentration of each nutrient is identified based on the hump in three dimensional plot.

\section{Enzyme assays}

The extracellular amylase and pullulanase activities from the clarified samples were measured by incubating $0.5 \mathrm{~mL}$ appropriately diluted enzyme sample with $0.5 \mathrm{~mL}$ of $1 \%$ (w/v) starch solution and pullulan solution in $2 \mathrm{~mL}$ of $0.1 \mathrm{M}$ acetate buffer (pH 5.5) at $70{ }^{\circ} \mathrm{C}$ for $30 \mathrm{~min}$, respectively. After incubation, the reaction was stopped by cooling the tubes in an ice bath. The reducing sugars released by enzymatic hydrolysis of soluble starch and pullulan were determined by addition of $1 \mathrm{~mL}$ of 3,5-dinitrosalicylic acid (Miller, 1959). A separate blank was set up for each sample to correct the non enzymatic release of sugars. One unit of amylase or pullulanase is defined as the rate 
Table 5: Experimental and predicted pullulanase and amylase activities of thermostable amylopullulanase produced by C. thermosulfurogenes SVM17 in solid state fermentation

\begin{tabular}{|c|c|c|c|c|c|c|}
\hline \multirow[b]{2}{*}{$\begin{array}{l}\text { Combination } \\
\text { number }\end{array}$} & \multicolumn{3}{|c|}{ Pullulanase activity (U/kg BB) } & \multicolumn{3}{|c|}{ Amylase activity (U/kg BB) } \\
\hline & $\begin{array}{l}\text { Experimental } \\
\text { yield }\end{array}$ & $\begin{array}{l}\text { Predicted } \\
\text { yield }\end{array}$ & residual & $\begin{array}{l}\text { Experimental } \\
\text { yield }\end{array}$ & $\begin{array}{l}\text { Predicted } \\
\text { Yield }\end{array}$ & Residual \\
\hline 1 & 19,840 & 19,512 & 328 & 10,635 & 13,169 & -2534 \\
\hline 2 & 25,260 & 24,093 & 1167 & 21,432 & 19,916 & 1516 \\
\hline 3 & 21,800 & 22,089 & -289 & 15,400 & 15,340 & 60 \\
\hline 4 & 26,400 & 25,202 & 1198 & 19,700 & 19,714 & -14 \\
\hline 5 & 19,400 & 18,689 & 711 & 14,440 & 13,425 & 1015 \\
\hline 6 & 23,650 & 23,919 & -269 & 18,600 & 20,213 & -1613 \\
\hline 7 & 22,550 & 20,950 & 1600 & 16,730 & 15,046 & 1684 \\
\hline 8 & 22,780 & 24,711 & -1931 & 18,760 & 19,461 & -701 \\
\hline 9 & 19,700 & 18,783 & 917 & 12,740 & 12,862 & -122 \\
\hline 10 & 27,050 & 25,403 & 1647 & 18,950 & 19,109 & -159 \\
\hline 11 & 20,120 & 19,934 & 186 & 13,760 & 14,531 & -771 \\
\hline 12 & 24,950 & 25,085 & -135 & 19,020 & 18,404 & 616 \\
\hline 13 & 19,320 & 19,361 & -41 & 12,790 & 13,370 & -580 \\
\hline 14 & 26,240 & 26,630 & -390 & 19,740 & 19,658 & 82 \\
\hline 15 & 21,650 & 20,196 & 1454 & 13,240 & 14,489 & -1249 \\
\hline 16 & 26,200 & 25,996 & 204 & 18,190 & 18,403 & -213 \\
\hline 17 & 20,830 & 20,629 & 201 & 14,330 & 14,337 & -7 \\
\hline 18 & 24,010 & 24,144 & -134 & 20,390 & 19,934 & 456 \\
\hline 19 & 22,570 & 22,310 & 260 & 16,310 & 15,151 & 1159 \\
\hline 20 & 23,350 & 24,356 & -1006 & 18,080 & 18,374 & -294 \\
\hline 21 & 18,860 & 19,812 & -952 & 13,980 & 14,600 & -620 \\
\hline 22 & 23,700 & 23,976 & 276 & 21,380 & 20,238 & 1142 \\
\hline 23 & 20,890 & 21,177 & -287 & 13,360 & 14,864 & -1504 \\
\hline 24 & 23,320 & 23,872 & 552 & 18,900 & 18,128 & 772 \\
\hline 25 & 20,850 & 18,451 & 358 & 14,350 & 13,626 & 724 \\
\hline 26 & 20,760 & 24,005 & 2399 & 17,380 & 18,721 & -1341 \\
\hline 27 & 18,780 & 18,706 & -3245 & 13,860 & 13,937 & -77 \\
\hline 28 & 24,000 & 22,791 & 74 & 16,320 & 16,659 & -339 \\
\hline 29 & 18,600 & 19,035 & 1209 & 13,710 & 14,141 & -431 \\
\hline 30 & 26,490 & 25,238 & -435 & 18,650 & 19,278 & -628 \\
\hline 31 & 17,320 & 18,974 & 1252 & 13,850 & 13,901 & -51 \\
\hline 32 & 22,690 & 23,708 & 1654 & 18,100 & 16,665 & 1435 \\
\hline 33 & 25,200 & 26,073 & -1018 & 17,610 & 18,403 & -793 \\
\hline 34 & 23,590 & 26,073 & -873 & 18,100 & 18,403 & -303 \\
\hline 35 & 27,110 & 16,282 & -1323 & 17,720 & 18,403 & -683 \\
\hline 36 & 21,800 & 25,570 & -1962 & 19,450 & 18,403 & 1047 \\
\hline 37 & 24,750 & 21,606 & 1413 & 18,810 & 18,403 & 407 \\
\hline 38 & 21,000 & 22,653 & -1166 & 18,920 & 18,403 & 517 \\
\hline 39 & 22,380 & 22,353 & 617 & 19,780 & 18,403 & 1377 \\
\hline 40 & 23,400 & 24,310 & -910 & 19,420 & 18,403 & 1017 \\
\hline 41 & 14,320 & 16,663 & -2343 & 13,620 & 12,291 & 1329 \\
\hline 42 & 27,010 & 25,987 & 1032 & 21,120 & 21,802 & -682 \\
\hline 43 & 20,440 & 21,987 & -1547 & 20,860 & 19,633 & 1227 \\
\hline 44 & 23,270 & 23,034 & 236 & 18,612 & 19,192 & -580 \\
\hline 45 & 20,240 & 22,734 & -2494 & 17,620 & 17,380 & 240 \\
\hline 46 & 24,010 & 22,827 & 1183 & 18,050 & 17,642 & 408 \\
\hline 47 & 25,060 & 25,052 & 8 & 19,460 & 20,041 & -581 \\
\hline 48 & 22,840 & 24,159 & -1319 & 19,500 & 18,271 & 1229 \\
\hline 49 & 20,140 & 23,426 & -3286 & 17,410 & 16,241 & 1169 \\
\hline 50 & 24,230 & 22,255 & 1975 & 15,150 & 15,671 & -521 \\
\hline 51 & 26,180 & 24,540 & 1637 & 19,240 & 19,297 & -57 \\
\hline & & & 186 & & & (continued) \\
\hline
\end{tabular}




\begin{tabular}{lllllll}
52 & 26,940 & 24,540 & 2397 & 19,450 & 19,297 & 153 \\
53 & 25,930 & 24,543 & 1387 & 17,590 & 19,297 & -1707 \\
54 & 25,680 & 24,543 & 1137 & 17,670 & 19,297 & -1627 \\
\hline
\end{tabular}

Experiments were conducted in $120 \mathrm{~mL}$ anaerobic serum vials containing $10 \mathrm{~g}$ of wheat bran with respective concentrations of nutrients (Table 1) dissolved in distilled water, incubated at $60^{\circ} \mathrm{C}$ for $72 \mathrm{~h}$. The enzyme activities were assayed under standard assay conditions

of formation ( $1 \mu$ mole) of reducing sugars (as glucose equivalents) per min under standard assay conditions.

\section{RESULTS AND DISCUSSION}

C. thermosulfurogenes SVM17 grew optimally at $60{ }^{\circ} \mathrm{C}$, and produced 2,600 and 1,300 $\mathrm{U}$ of thermostable amylase and pullulanase activities, respectively per liter of culture broth in submerged fermentation. In solid state fermentation, the strain SVM17 produced on an average of 9,221 and $10,080 \mathrm{U}$ of thermostable amylase and pullulanase, respectively per kilogram of moistened bacterial bran (BB) grown at $60^{\circ} \mathrm{C}$ in $72 \mathrm{~h}$.

\section{Effect of nutrients on enzyme production}

The enzyme yields of $C$. thermosulfurogenes SVM17 from screening of fifteen nutrients in sixteen experiments using Plackett-Burman design are shown in Table 2. It is clear from the Table 2 that the strain produced highest average yields of amylase $(18,968 \mathrm{U} / \mathrm{kg} \mathrm{BB})$ and pullulanase $(28,426 \mathrm{U} / \mathrm{kg} \mathrm{BB})$ in combinations 7 of the design, followed by 6 and 2 . The data on enzyme yields were subjected to statistical analysis to obtain regression coefficients and $t$-values (Table 3 ). From Table 3 , it is clear that maltose, xylose, lactose, potato flour, bajra flour, jowar flour, peptone, CSL, calcium chloride and manganous chloride showed significant effects on yields of both amylase and pullulanase. Apart from these, sucrose, soluble starch, wheat flour and sodium chloride were also significant on amylase synthesis but not on pullulanase synthesis. Effect of yeast extract was significant on synthesis of both the enzymes. Among carbon sources screened, maltose and xylose were found to be the best for maximum enzyme production, followed by lactose. Soluble starch influenced synthesis of amylase but not pullulanase production. Sucrose influenced pullulanase but not on amylase production. Since maltose greatly influenced both the enzymes production, it was selected for optimization studies. Among complex organic sources, potato flour and bajra flour showed positive effects on enzyme production. Therefore, bajra flour was selected for further optimization studies. Among nitrogen sources screened, peptone showed greater effect on enzyme production. Calcium chloride and manganous chloride were highly significant among trace mineral sources screened and therefore included for optimization.

Literature gives no information on the production of thermostable amylopullulanase in SSF. Maltose was reported to be the inducer of $\beta$-amylase production by $C$. thermocellum SS8 (Swamy et al., 1994) and C. thermosulfurogenes (Hyun and Zeikus, 1985a). In contrast, maltose was reported to be repressor for production of amylase by Bacillus stearothermophilus (Srivastava and Baruah, 1986). Swamy and Seenayya (1996b) reported that corn steep liquor in combination with yeast extract were the best nitrogen source for thermostable $\alpha$-amylase and pullulanase production in SmF by $C$. thermosulfurogenes SV9. The significant effect of corn steep liquor on enzyme production could be due to presence of growth factors in it (Srinivas et al., 1994).

To identify the most important factor, screening of medium components adopting Plackett-Burman design have been employed for production of fungal proteinase (Ramana Murthy, 1994), cyclosporin A (Ramana Murthy et al., 1999), $\beta$-amylase and pullulanase (Rama Mohan Reddy et al., 1999b), echinocandin B (Cockshott and Sullivan Gary, 2001), biohydrogen (Pan et al., 2008) and alkaline protease (Reddy et al., 2008).

\section{Response surface analysis for the optimization of levels of medium components}

The uncoded (natural) and coded (real) values of five medium components are given in Table 4, which gives various concentrations to be attempted. Mathematical relationship of the response $Y_{1}$ (pullulanase activity) and $\mathrm{Y}_{2}$ (amylase activity) on these variables were calculated by second order polynomial equations.

$\mathrm{Y}_{1}$ (Pullulanase activity) $=26650.8+328.80 \mathrm{X}_{1}+261.70 \mathrm{X}_{2}$ $+23.20 X_{3}-223.20 X_{4}-292.70 X_{5}-1139.10 X_{1}^{2}-$ $841.60 X_{2}^{2}-774.11 X_{3}^{2}-317.80 X_{4}^{2}-759.10 X_{5}^{2}-$ $367.20 X_{1} X_{2}+162.205 X_{1} X_{3}+509.70 X_{1} X_{4}-266.60 X_{1} X_{5}-$ $79.10 X_{2} X_{3}-356.60 X_{2} X_{4}-224.10 X_{2} X_{5}+350.3 X_{3} X_{4}+$ $16.0 X_{3} X_{5}-362.20 X_{4} X_{5}-577.40$

$\mathrm{Y}_{2}$ (amylase activity) $=17508.20+2377.7 \mathrm{X}_{1}-110.3 \mathrm{X}_{2}+$ $65.6 X_{3}-442.4 X_{4}-142.4 X_{5}-562.6 X_{1}{ }^{2}+28.90 X_{2}{ }^{2}-$ $446.40 X_{3}^{2}-35.10 X_{4}^{2}-835.10 X_{5}^{2}-593.3 X_{1} X_{2}+$ $10.40 X_{1} X_{3}-125.2 X_{1} X_{4}-287.7 X_{1} X_{5}-137.60 X_{2} X_{3}-$ $125.70 X_{2} X_{4}-339.50 X_{2} X_{5}+63.00 X_{3} X_{4}+1.80 X_{3} X_{5}-$ $101.3 X_{4} X_{5}-894.30$

where, $Y_{1}$ and $Y_{2}$ are the predicted pullulanase and amylase activities, respectively. $X_{1}, X_{2}, X_{3}, X_{4}$ and $X_{5}$ are the coded values of maltose, peptone, manganous chloride, calcium chloride and bajra flour, respectively. 
Table 6: Significance of regression coefficients of pullulanase activity (in SSF) model*

\begin{tabular}{|c|c|c|c|c|}
\hline Process variable & Regression coefficient & Computed t-value & Probability & Significance Level \\
\hline INTERCEPT & 26650.80 & 19.26 & 0.0000 & \\
\hline $\mathrm{X}_{1}$ Maltose & 328.80 & 8.59 & 0.0000 & $* * *$ \\
\hline $\mathrm{X}_{2}$ Peptone & 261.70 & 0.97 & 0.3430 & \\
\hline $\mathrm{X}_{3} \mathrm{MnCl}_{2} 4 \mathrm{H}_{2} \mathrm{O}$ & 23.20 & 0.09 & 0.9323 & \\
\hline $\mathrm{X}_{4} \mathrm{CaCl}_{2} 2 \mathrm{H}_{2} \mathrm{O}$ & -223.20 & -0.82 & 0.4175 & \\
\hline$X_{5}$ Bajra flour & -292.70 & -1.08 & 0.2899 & \\
\hline $\mathrm{X}_{1}^{2}$ & -1139.10 & -3.51 & 0.0016 & $* * *$ \\
\hline$x_{2}^{2}$ & -841.60 & -2.60 & 0.0153 & * \\
\hline$x_{3}^{2}$ & -774.11 & -2.39 & 0.0245 & * \\
\hline$x_{4}^{2}$ & -317.80 & -0.98 & 0.3359 & \\
\hline$X_{5}^{2}$ & -759.10 & -2.34 & 0.0271 & * \\
\hline$X_{1} X_{2}$ & -367.20 & -1.21 & 0.2364 & \\
\hline$X_{1} X_{3}$ & 162.20 & 0.54 & 0.5970 & \\
\hline $\mathrm{X}_{1} \mathrm{X}_{4}$ & 509.70 & 1.68 & 0.1045 & \\
\hline$X_{1} X_{5}$ & -266.60 & -0.87 & 0.3870 & \\
\hline$X_{2} X_{3}$ & -79.10 & -0.26 & 0.7962 & \\
\hline $\mathrm{X}_{2} \mathrm{X}_{4}$ & -356.60 & -1.18 & 0.2499 & \\
\hline$X_{2} X_{5}$ & -224.10 & -0.74 & 0.4662 & \\
\hline$X_{3} X_{4}$ & 350.30 & 1.16 & 0.2581 & \\
\hline$X_{3} X_{5}$ & 16.00 & 0.01 & 0.9959 & \\
\hline$X_{4} X_{5}$ & -362.20 & -1.19 & 0.2427 & \\
\hline Block & -577.40 & -0.91 & 0.3722 & \\
\hline
\end{tabular}

*Significance levels of regression coefficients are given as ${ }^{\star \star *} 99.9 \%,{ }^{* *} 99.0 \%$ and ${ }^{*} 95.0 \%$ by $t$-test

Regression coefficients, $t$-values and $\mathrm{P}$ values of pullulanase activity were obtained by subjecting the pullulanase yields (Table 5 ) to statistical analysis using 'Indostat' statistical software.

The predicted and experimental yield of pullulanase and amylase for 54 experiments are given in Table 5. The regression coefficients and $t$-values of pullulanase and amylase are given in Tables 6 and 7, respectively. Analysis of variance (ANOVA) is required to test the significance and adequacy of the model. Summary of analysis of variance for evaluation of second order polynomial model for pullulanase and amylase are presented in Tables 8 and 9, respectively. From the ANOVA, it is observed that, the model for pullulanase and amylase activities were highly significant, as it was evident from the Fisher, F-test and a very low probability value. The $F$ values corresponding to pullulanase and amylase was 5.195 and 9.350 , respectively and $P$ values of the models was less than 0.00007 and 0.000001 for pullulanase and amylase, respectively. Greater the $F$ value is from one, the more certain that the factors explain adequately the variation in the data about its mean and the estimated factor effects are real. $P$ values were used as a tool to check the significance of each of the coefficient which in turn, was necessary to understand the pattern of the mutual interactions between the test variables. Smaller the magnitude of $P$ more significant is the corresponding coefficient (Khuri and Cornell, 1987). Goodness of the model was checked by the coefficient of determination, $R^{2}$. Closer the values of $R$ (multiple correlation coefficient) to 1 , better the correlation between observed and predicted values. Hence we observed the values of $R$ for pullulanase $(0.901)$ and amylase $(0.931)$ indicate a good agreement between the experimental and predicted yields, respectively. The $\mathrm{R}^{2}$ for pullulanase and amylase were 0.81 and 0.87 , respectively. Coefficient of variation $(\mathrm{CV})$ indicates the degree of precision with which the treatments are compared. Usually, higher the value of $\mathrm{CV}$, lower is the reliability of experiments performed. Here a lower value of CV for pullulanase (7.56) and amylase (7.16) indicates a greater reliability of the experiments performed.

From Table 6 (the significance of regression coefficients of pullulanase activity model), it is observed that the linear terms of maltose were highly significant on pullulanase yields, followed by quadratic terms of maltose, manganous chloride, peptone and bajra flour. None of the calcium chloride terms were significant on pullulanase yield but the interactive terms of any of these test variables on pullulanase activity were found to be significant. Similarly, from Table 7 (the significance of regression coefficients of amylase activity model), it is observed that the linear terms of maltose and quadratic terms of bajra flour were highly significant on amylase yields followed by linear terms of calcium chloride, quadratic terms of maltose and manganous chloride. The interactive terms of maltose and peptone was found significant on amylase activity. However, none of the linear and quadratic terms of peptone were significant on amylase activity. 


\section{Interactions among the nutrients}

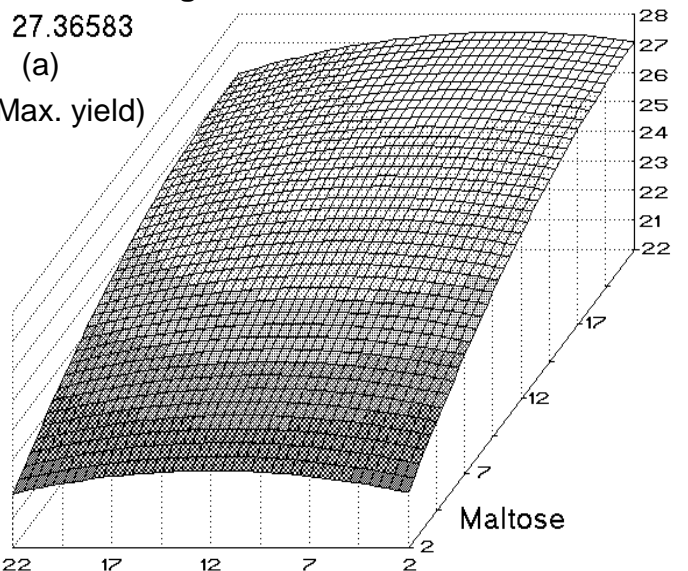

Baira flour
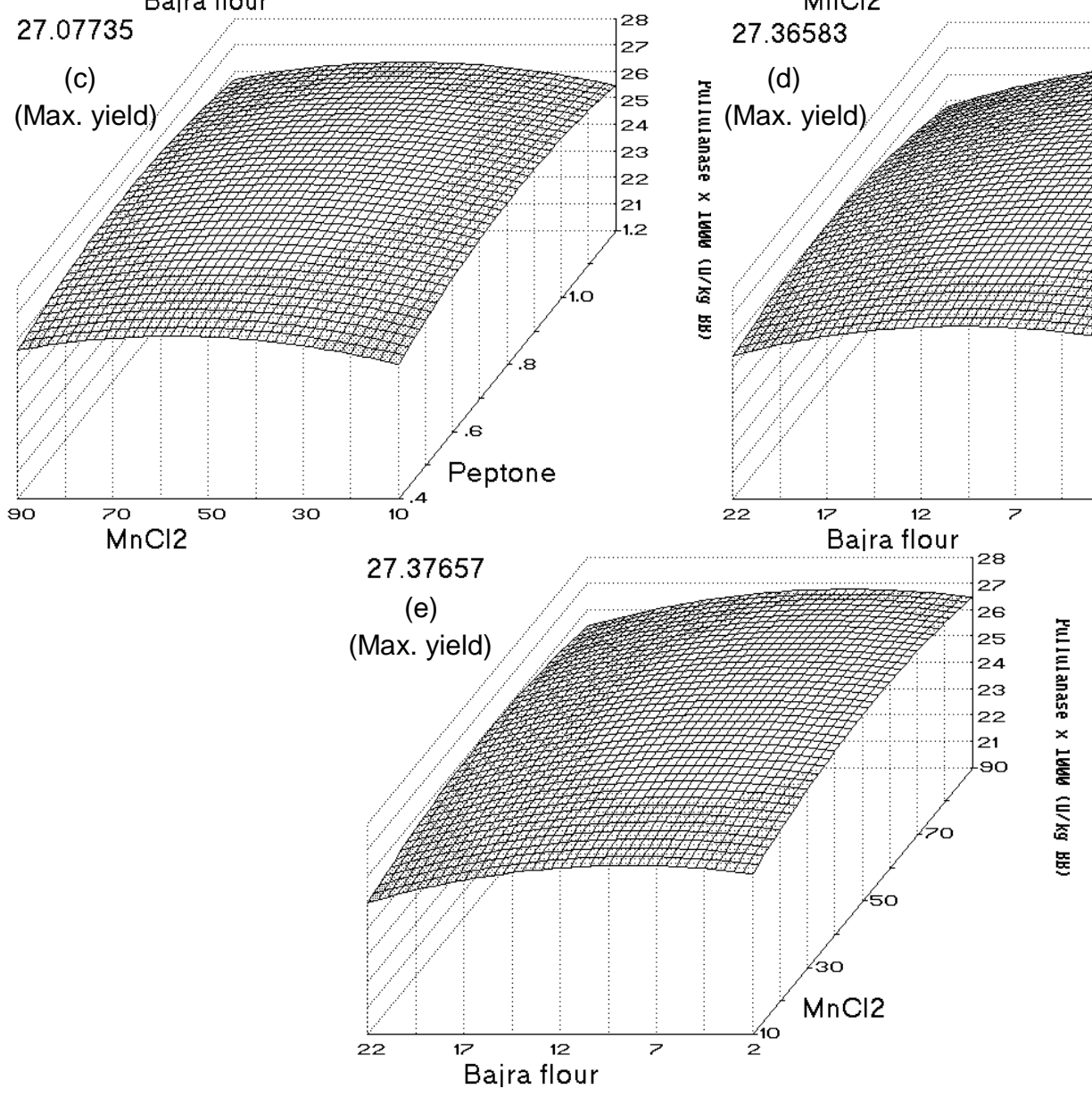

Figure 1: Response surface plot for the production of thermostable amylopullulanase by $C$. thermosulfurogenes SVM17 in SSF as a function of varying concentrations of (a) maltose and bajra flour on the yield of pullulanase when the peptone $(0.8 \% \mathrm{w} / \mathrm{w}), \mathrm{MnCl}_{2} \cdot 4 \mathrm{H}_{2} \mathrm{O}$ $(50.0 \mathrm{ppm} \mathrm{w} / \mathrm{w})$ and $\mathrm{CaCl}_{2} \cdot 2 \mathrm{H}_{2} \mathrm{O}(15.0 \mathrm{ppm} \mathrm{w} / \mathrm{w})$ were held at zero level; (b) maltose and $\mathrm{MnCl}_{2} \cdot 4 \mathrm{H}_{2} \mathrm{O}$ on the yield of pullulanase when the peptone $(0.8 \% \mathrm{w} / \mathrm{w}), \mathrm{CaCl}_{2} \cdot 2 \mathrm{H}_{2} \mathrm{O}(15.0 \mathrm{ppm} \mathrm{w} / \mathrm{w})$ and bajra flour $(12.0 \% \mathrm{w} / \mathrm{w})$ were held at zero level; (c) peptone and $\mathrm{MnCl}_{2} \cdot 4 \mathrm{H}_{2} \mathrm{O}$ on the yield of pullulanase when the maltose $(12.0 \% \mathrm{w} / \mathrm{w}), \mathrm{CaCl}_{2} \cdot 2 \mathrm{H}_{2} \mathrm{O}(15.0 \mathrm{ppm} \mathrm{w} / \mathrm{w})$ and bajra flour $(12.0 \%$ w/w) were held at zero level; (d) peptone and bajra flour on the yield of pullulanase when the maltose $(12.0 \% \mathrm{w} / \mathrm{w}), \mathrm{MnCl}_{2} \cdot 4 \mathrm{H}_{2} \mathrm{O}(50.0 \mathrm{ppm} \mathrm{w} / \mathrm{w})$ and $\mathrm{CaCl}_{2} \cdot 2 \mathrm{H}_{2} \mathrm{O}(15.0 \mathrm{ppm} \mathrm{w} / \mathrm{w})$ were held at zero level; (e) $\mathrm{MnCl}_{2} \cdot 4 \mathrm{H}_{2} \mathrm{O}$ and bajra flour on the yield of pullulanase when the maltose $(12.0 \% \mathrm{w} / \mathrm{w})$, peptone $(0.8 \% \mathrm{w} / \mathrm{w})$ and $\mathrm{CaCl}_{2} \cdot 2 \mathrm{H}_{2} \mathrm{O}(15.0 \mathrm{ppm} \mathrm{w} / \mathrm{w})$ were held at zero level 

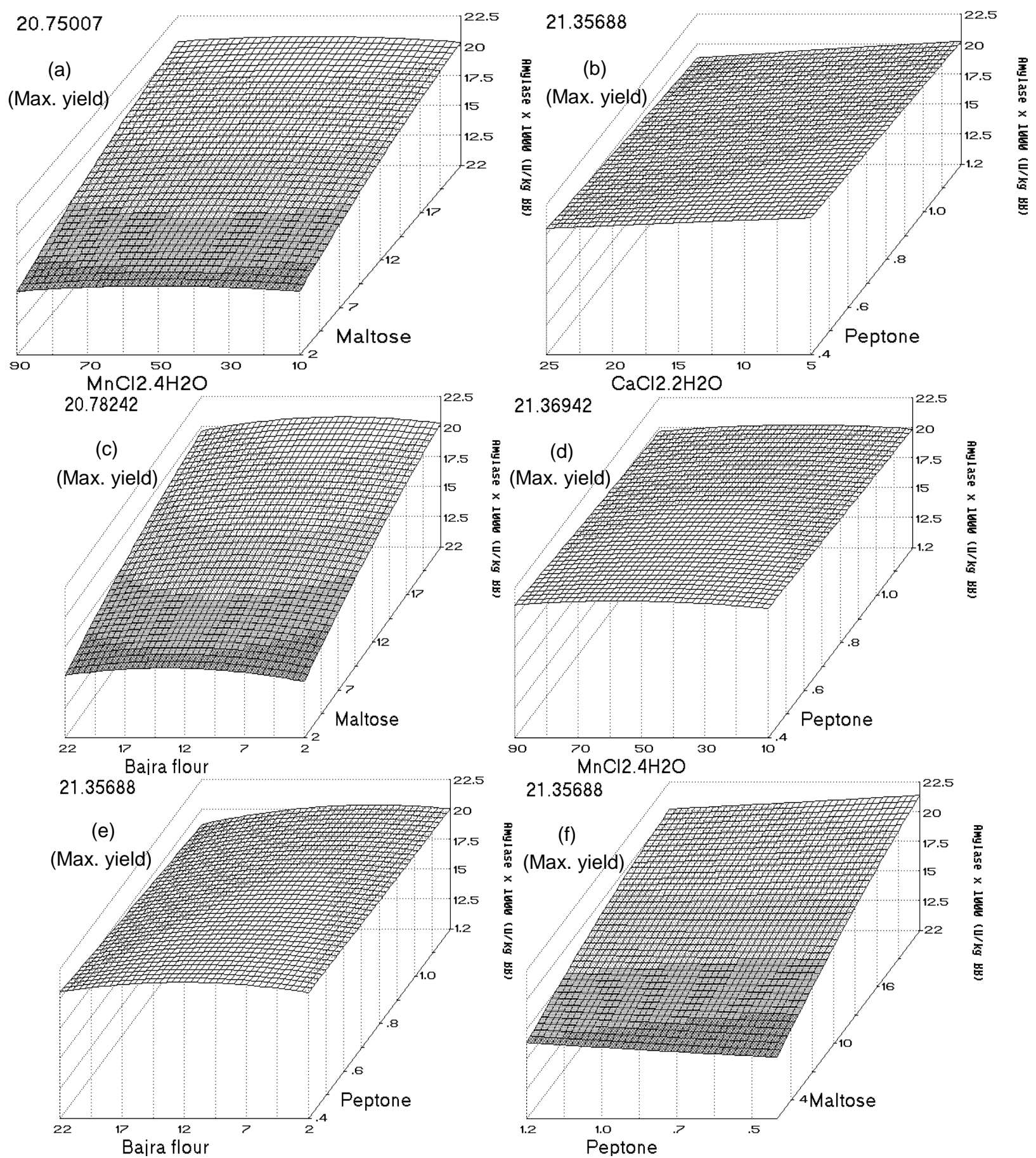

Figure 2: Response surface plot for the production of thermostable amylopullulanase by $C$. thermosulfurogenes SVM17 in SSF as a function of varying concentrations of (a) maltose and $\mathrm{MnCl}_{2} \cdot 4 \mathrm{H}_{2} \mathrm{O}$ on the yield of amylase when the peptone $(0.8 \% \mathrm{w} / \mathrm{w}), \mathrm{CaCl}_{2} \cdot 2 \mathrm{H}_{2} \mathrm{O}$ $(15.0 \mathrm{ppm} \mathrm{w} / \mathrm{w})$ and bajra flour $\left(12.0 \% \mathrm{w} / \mathrm{w}\right.$ ) were held at zero level; (b) peptone and $\mathrm{CaCl}_{2} \cdot 2 \mathrm{H}_{2} \mathrm{O}$ on the yield of amylase when the maltose $(12.0 \% \mathrm{w} / \mathrm{w}), \mathrm{MnCl}_{2} \cdot 4 \mathrm{H}_{2} \mathrm{O}(50.0 \mathrm{ppm} \mathrm{w} / \mathrm{w})$ and bajra flour $(12.0 \% \mathrm{w} / \mathrm{w})$ were held at zero level; (c) maltose and bajra flour on the yield of amylase when the peptone $(0.8 \% \mathrm{w} / \mathrm{w}), \mathrm{MnCl}_{2} \cdot 4 \mathrm{H}_{2} \mathrm{O}(50.0 \mathrm{ppm} \mathrm{w} / \mathrm{w})$ and $\mathrm{CaCl}_{2} \cdot 2 \mathrm{H}_{2} \mathrm{O}(15.0 \mathrm{ppm}$ w/w) were held at zero level; (d) peptone and $\mathrm{MnCl}_{2} \cdot 4 \mathrm{H}_{2} \mathrm{O}$ on the yield of amylase when the maltose $(12.0 \% \mathrm{w} / \mathrm{w}), \mathrm{CaCl}_{2} \cdot 2 \mathrm{H}_{2} \mathrm{O}(15.0 \mathrm{ppm}$ w/w) and bajra flour $(12.0 \% \mathrm{w} / \mathrm{w})$ were held at zero level; (e) peptone and bajra flour on the yield of amylase when the maltose $(12.0 \% \mathrm{w} / \mathrm{w}), \mathrm{MnCl}_{2} \cdot 4 \mathrm{H}_{2} \mathrm{O}$ $(50.0 \mathrm{ppm} \mathrm{w} / \mathrm{w})$ and $\mathrm{CaCl}_{2} \cdot 2 \mathrm{H}_{2} \mathrm{O}(15.0 \mathrm{ppm} \mathrm{w} / \mathrm{w})$ were held at zero level; (f) maltose and peptone and on the yield of amylase when the $\mathrm{MnCl}_{2} \cdot 4 \mathrm{H}_{2} \mathrm{O}(50.0 \mathrm{ppm} \mathrm{w} / \mathrm{w}), \quad \mathrm{CaCl}_{2} \cdot 2 \mathrm{H}_{2} \mathrm{O}(15.0 \mathrm{ppm} \mathrm{w} / \mathrm{w})$ and bajra flour $(12.0 \% \mathrm{w} / \mathrm{w})$ were held at zero level 
Table 7: Significance of regression coefficients of amylase activity (in SSF) model ${ }^{\star}$

\begin{tabular}{|c|c|c|c|c|}
\hline Process variable & $\begin{array}{c}\text { Regression } \\
\text { coefficient }\end{array}$ & Computed t-value & Probability & $\begin{array}{c}\text { Significance } \\
\text { level }\end{array}$ \\
\hline INTERCEPT & 17508.20 & 25.85 & 0.0000 & \\
\hline $\mathrm{X}_{1}$ Maltose & 2377.70 & 12.16 & 0.0000 & $* * *$ \\
\hline $\mathrm{X}_{2}$ Peptone & -110.30 & -0.56 & 0.5765 & \\
\hline $\mathrm{X}_{3} \mathrm{MnCl}_{2} 4 \mathrm{H}_{2} \mathrm{O}$ & 65.60 & 0.34 & 0.7395 & \\
\hline $\mathrm{X}_{4} \mathrm{CaCl}_{2} 2 \mathrm{H}_{2} \mathrm{O}$ & -442.40 & -2.26 & 0.0306 & * \\
\hline$X_{5}$ Bajra flour & -142.40 & -0.73 & 0.4716 & \\
\hline$X_{1}^{2}$ & -562.60 & -2.63 & 0.0129 & * \\
\hline$x_{2}^{2}$ & 28.90 & 0.14 & 0.8934 & \\
\hline$x_{3}^{2}$ & -446.40 & -2.09 & 0.0447 & * \\
\hline $\mathrm{X}_{4}^{2}$ & -35.10 & -0.16 & 0.8704 & \\
\hline$X_{5}^{2}$ & -835.10 & -3.91 & 0.0005 & $* * *$ \\
\hline$X_{1} X_{2}$ & -593.30 & -2.71 & 0.0106 & * \\
\hline $\mathrm{X}_{1} \mathrm{X}_{3}$ & 10.40 & 0.05 & 0.9623 & \\
\hline $\mathrm{X}_{1} \mathrm{X}_{4}$ & -125.20 & -0.57 & 0.5704 & \\
\hline$X_{1} X_{5}$ & - 287.70 & -1.32 & 0.1975 & \\
\hline$X_{2} X_{3}$ & -137.60 & -0.63 & 0.5335 & \\
\hline $\mathrm{X}_{2} \mathrm{X}_{4}$ & -125.70 & -0.58 & 0.5692 & \\
\hline$X_{2} X_{5}$ & -339.50 & -1.55 & 0.1303 & \\
\hline $\mathrm{X}_{3} \mathrm{X}_{4}$ & 63.00 & 0.29 & 0.7749 & \\
\hline$X_{3} X_{5}$ & 1.80 & 0.01 & 0.9935 & \\
\hline $\mathrm{X}_{4} \mathrm{X}_{5}$ & -101.30 & -0.46 & 0.6461 & \\
\hline Block & 894.30 & 2.26 & 0.0311 & \\
\hline
\end{tabular}

* Significance levels of regression coefficients are given as *** $99.9 \%,{ }^{\star *} 99.0 \%$ and ${ }^{*} 95.0 \%$ by t-test.

Regression coefficients, t-values and $\mathrm{P}$ values of amylase activity were obtained by subjecting the amylase yields (Table 5 ) to statistical analysis using 'Indostat' statistical software.

Figures 1a-e and 2a-f are the significant response surface curves for pullulanase and amylase activities of thermostable amylopullulanase, respectively, as a function of concentrations of two medium components with other three components held at zero level. From the response surface plots, it is easy and convenient to understand the interactions between two nutrients and also to locate their optimum levels.

From Figures $1 \mathrm{a}$ and $1 \mathrm{~b}$, it is observed that the pullulanase activity increased up on increasing the concentrations of maltose from $2-22 \%$. Similarly, the enzyme yield also increased on increasing the concentration of peptone from $0.2-0.8 \%$ and any further increase in its concentration, showed gradual decrease in enzyme yield (Figures $1 \mathrm{c}$ and $1 \mathrm{~d}$ ). Therefore, $0.8 \%$ of peptone was found to be optimum for pullulanase activity. The maximum enzyme yields were recorded when the concentration of manganous chloride increased from 10$50 \mathrm{ppm}$ (Figures 1b, 1c and 1e) and bajra flour 2-10\% (Figures 1a, 1d and 1e). On further increase in their concentrations, a gradual decrease in enzyme yields was observed. Therefore, $50 \mathrm{ppm}$ of manganous chloride and $10 \%$ bajra flour was considered favorable for maximum yield of pullulanase.

It is clear from response surface plots (Figures $2 \mathrm{a}, 2 \mathrm{c}$ and $2 \mathrm{f}$ ), that the yield of amylase increased on increasing the concentration of maltose from $2-22 \%$. The increase was more pronounced at lower concentrations of peptone (Figure 2f). Therefore, high levels of maltose and low levels of peptone are favorable for enzyme production. Similarly, maximum amylase activity was observed with increasing concentration of manganous chloride from 10$50 \mathrm{ppm}$ (Figure 2a) and bajra flour from 2-12\% (Figure 2c). Further increase in their concentrations resulted in gradual decrease in amylase activity. Therefore, for optimum enzyme yields, $50 \mathrm{ppm}$ of manganous chloride and $12 \%$ bajra flour should be considered. The effect of peptone was more significant on amylase yields at higher concentrations of maltose (Figure 2f), at lower levels of calcium chloride (Figure 2b) and moderate levels of manganous chloride (50 ppm) and bajra flour (12\%) (Figures $2 \mathrm{~d}$ and 2e). This indicates that lower levels of calcium chloride, moderate levels of manganous chloride and bajra flour are most favorable for maximum amylase activity at low concentrations of peptone.

From the above observations, it is clear that the maximum pullulanase and amylase activities were observed when the concentrations of test variables lie in the following ranges (\%w/w): maltose, 17-22; peptone, 0.4-0.8; manganous chloride, $50 \mathrm{ppm}$; calcium chloride, 5-15 ppm and bajra flour 7-10.

Based on the above observations, the model predicted (\% w/w): maltose, 22; peptone, 0.8; $\mathrm{MnCl}_{2} \cdot 4 \mathrm{H}_{2} \mathrm{O}$, $50 \mathrm{ppm} ; \mathrm{CaCl}_{2}, 15 \mathrm{ppm}$ and bajra flour, 11 were required for the maximum production of the enzyme. The low and high levels of $\mathrm{CaCl}_{2}$ decreased the pullulanase and amylase activities, respectively. Keeping in view of both enzyme activities, we have fixed calcium chloride at zero 
Table 8: Analysis of variance (ANOVA) table: Effect of medium components on pullulanase activity of amylopullulanase produced by $C$. thermosulfurogenes SVM17 in SSF

\begin{tabular}{|c|c|c|c|c|c|}
\hline Source of variation & $\begin{array}{c}\text { Degrees of } \\
\text { Freedom }\end{array}$ & Sum of squares & Mean squares & F-ratio & Probability \\
\hline Block & 1 & 6986700.00 & 6986700.00 & 2.379 & 0.13508 \\
\hline Model & 21 & 320402250.00 & 15257250.00 & 5.195 & 0.00007 \\
\hline Residual & 26 & 76366580.00 & 2937180.00 & & \\
\hline Total & 47 & 403755540.00 & 8590540.00 & & \\
\hline
\end{tabular}

Root mean square error $=1713.82, \mathrm{CV}=7.56 \%, \mathrm{R}^{2}$ (coefficient of determination) $=0.81, \mathrm{R}=0.901$, adjusted $\mathrm{R}^{2}=0.65809$

Table 9: Analysis of variance (ANOVA) table: Effect of medium components on amylase activity of amylopullulanase produced by $C$. thermosulfurogenes SVM17 in SSF

\begin{tabular}{lcrrrr}
\hline Source of variation & $\begin{array}{c}\text { Degrees of } \\
\text { Freedom }\end{array}$ & Sum of squares & Mean squares & F-ratio & Probability \\
\hline Block & 1 & 17994220.00 & 17994220.00 & 11.767 & 0.00168 \\
Model & 21 & 300260820.00 & 14298130.00 & 9.350 & 0.00000 \\
Residual & 32 & 48933160.00 & 1529160.00 & & \\
Total & 53 & 367188190.00 & 6928080.00 & & \\
\hline
\end{tabular}

Root mean square error $=1236.59, \mathrm{CV}=7.16 \%, \mathrm{R}^{2}$ (coefficient of determination) $=0.87, \mathrm{R}=0.931$, adjusted $\mathrm{R}^{2}=0.77928$

Table 10: Experimental verification of combined effect of optimized medium on the response of amylopullulanase in SSF

\begin{tabular}{|c|c|c|c|c|c|c|c|c|c|}
\hline \multirow[t]{3}{*}{$\begin{array}{l}\text { Medium } \\
\text { components }\end{array}$} & \multirow{3}{*}{$\begin{array}{l}\text { Range } \\
\text { studied } \\
(w / w) \%\end{array}$} & \multicolumn{2}{|c|}{$\begin{array}{l}\text { Levels after } \\
\text { optimization }\end{array}$} & \multicolumn{6}{|c|}{ Enzyme yield (U/Kg BB) } \\
\hline & & \multirow[t]{2}{*}{ coded } & \multirow[t]{2}{*}{ uncoded } & \multicolumn{2}{|c|}{ Before optimization } & \multicolumn{4}{|c|}{ After optimization } \\
\hline & & & & Amylase & Pullulanase & $\begin{array}{l}\text { Amylase } \\
\text { Predicted }\end{array}$ & Experimental & $\begin{array}{l}\text { Pullulanase } \\
\text { Predicted }\end{array}$ & Experimental \\
\hline Maltose $\left(\mathrm{X}_{1}\right)$ & $2.0-22.0$ & 2 & 22.0 & & & & & & \\
\hline Peptone $\left(X_{2}\right)$ & $0.4-1.2$ & 0 & 0.8 & & & & & & \\
\hline $\begin{array}{l}\mathrm{MnCl}_{2} \cdot 4 \mathrm{H}_{2} \mathrm{O} \\
\left(\mathrm{X}_{3}\right)\end{array}$ & $10-90 \mathrm{ppm}$ & 0 & 50.0 & 9,220 & 10,080 & 21,050 & 20,130 & 26,310 & 28,970 \\
\hline $\mathrm{CaCl}_{2} \cdot 2 \mathrm{H}_{2} \mathrm{O}\left(\mathrm{X}_{4}\right)$ & 5-25 ppm & 0 & 15.0 & & & & & & \\
\hline Bajra flour $\left(X_{5}\right)$ & $2.0-22.0$ & -0.193 & 11.035 & & & & & & \\
\hline
\end{tabular}

level (i.e., $15 \mathrm{ppm}$, Table 10). By substituting the correspondingly coded concentration levels of the factors in to the regression equation, the maximum predictable response for pullulanase and amylase activities was calculated. The maximum yield of amylase and pullulanase obtained using the optimized medium was 20,130 and $28,970 \mathrm{U} / \mathrm{kg} \mathrm{BB}$, respectively. It was in correlation with the predicted yields (Table 10).

There are no reports available in literature on medium optimization for amylopullulanase production by SSF. However, statistical methods have been applied in other studies to optimize the medium components in SSF for the production of cyclosporine-A by Tolypocladium inflatum (Ramana Murthy et al., 1999), alkaline exopolygalactouronase by Bacillus subtilis RCK (Gupta et al., 2008), lipase by Candida rugosa (Venkat Rao et al., 1993), thermostable pullulanase by Clostridium thermosulfurogenes SV2 (Rama Mohan Reddy et al., 1999a), xylanase by Thermascus aurantiacus (Souza de O et al., 1999). In all these cases the product yields were higher in SSF than in SmF. Increase in the yield of
cyclosporin-A from $459-4843 \mathrm{mg} / \mathrm{kg}$ was achieved in SSF by using statistical method for optimization of medium (Ramana Murthy, et al., 1999). Similarly, yield of gibberelic acid and lipase activity were increased in about 11 and 3 folds, respectively (Pastrana et al., 1995; Venkat Rao et al., 1993). After medium optimization, the increase in pullulanase production by $C$. thermosulfurogenes SV2 was observed to be increased by $10 \%$ (Rama Mohan Reddy et al., 1999a). Therefore these studies indicate the feasibility study of SSF processes.

\section{CONCLUSIONS}

In the present study screening of nutrients employing Plackett-Burman design and optimization of nutrients concentration using response surface methodology for the production of thermostable amylopullulanase in SSF proved to be useful in increasing the yields of pullulanase and amylase by 182 and $106 \%$, respectively in a limited number of experiments. Hence the application of statistical experimental designs for production of 
thermostable amylopullulanase was found to be more promising as these designs are relatively simple and time saving. An overall increase in yield of pullulanase and amylase was found to be 22 and 8 folds, respectively in SSF after optimization when compared to SmF. Therefore SSF process is highly advantageous for production of valuable thermostable amylopullulanase over SmF process.

\section{ACKNOWLEDGEMENTS}

The author acknowledges Council of Scientific and Industrial Research (CSIR), New Delhi, India for providing funds.

\section{REFERENCES}

Archana, A. and Satyanarayana, T. (1997). Xylanase production by thermophilic Bacillus licheniformis A99 in solid-state fermentation. Enzyme and Microbial Technology 21, 12-17.

Box, G. E. P. and Wilson, K. B. (1951). On the experimental attainment of optimum conditions. Journal. R. Statistical Society, (series-B) 13, 1-45.

Brown, S. H. and Kelly, R. M. (1993). Characterization of amylolytic enzymes, having both $\alpha-1,4$ and $\alpha-1,6$ hydrolytic activity, from the thermophilic archea Pyrococcus furiosus and Thermococcus litoralis. Applied and Environmental Microbiology 59, 26142621.

Chauhan, K., Trivedi, U. and Patel, K. C. (2007). Statistical screening of medium components by Plackett-Burman design for lactic acid production by Lactobacillus sp. KCP01 using date juice. Bioresource Technology 98, 98-103.

Cochran, W. G. and Cox, G. M. (1957). Experimental designs. John Wiley, New York.

Cockshott, A. R. and Sullivan, G. R. (2001). Improving the fermentation medium for echinocandin $B$ production. part I: sequential statistical experimental design. Process Biochemistry 36, 647-660.

Dong, G., Vieille, C. and Zeikus, J. G. (1997). Cloning , sequencing and expression of the gene encoding amylopullulanase from Pyrococcus furiosus and biochemical characterization of the recombinent enzyme. Applied and Environmental Microbiology 63, 3577-3584.

Duffner, F. (2000). Desulfurococcus amylopullulanase. USP No. 6,043,074.

Fogarty, W. M. and Kelly, C. T. (1990). Recent advances in microbial amylases. In: Microbial enzymes and Biotechnology. Fogarty, W. M. and Kelly, C. T. (eds.). Elsevier Applied Science Publishers, London. 71-132.

Ganghofner, D., Kellermann, J., Staudenbauer, L.W and Bronnenmeier, K. (1998). Purification and properties of an amylopullulanase, a glucoamylase, and an $\alpha$-glucosidase in the amylolytic enzyme system of Thermoanaerobacterium thermosaccharolyticum. Bioscience Biotechnology and Biochemistry 62, 302-308.
Gessesse, A. and Mamo, G. (1999). A novel xylanase production by an alkaliphilic Bacillus sp. by using solid-state fermentation. Enzyme and Microbial Technology. 25, 68-72.

Gomes, I., Gomes, J. and Steiner, W. (2003). Highly thermostable amylase and pullulanase of the extreme thermophillic eubacterium Rhodothermus marinus: production and partial characterization. Bioresource Technology 90, 207-214.

Gong, X. and Chen, F. (1998). Influence of medium components on astaxanthin content and production of Haematococcus pluvial. Process Biochemistry 33, 385-391.

Greesham, R. L. (1983). Biotechnology In: Bioprocessing Rehun, H. J., Reed, G., Puhler, A. and Standler, P. (eds.). VCH Publishers, New York, USA 128-139.

Gupta, S., Kapoor, M., Sharma, K. K., Lavanya. M. Nair. and Kuhad, R. C. (2008). Production and recovery of an alkaline exopolygalacturonase from Bacillus subtilis RCK under solid state fermentation using statistical approach. Bioresource Technolology 99, 937-945.

Hyun, H. H. and Zeikus, J. G. (1985). General and biochemical characterization of thermostable extracellular $\beta$-amylase from Clostridium thermosulfurogenes. Applied and Environmental Microbiology 49, 1162-1167.

Jagannadha Rao, K., Kim, C-H. and Rhee, S-K. (2000). Statistical optimization of medium for the production of recombinant hirudin from saccharomyces cerevisiae using response surface methodology, Process Biochemistry 35, 639-647.

Khanna, S. and Srivastava, A. K. (2005). Statistical media optimization studies for growth and PHB production by Ralstonia eutropha. Process Biochemistry 40, 2173-2182.

Khuri, A. I. and Cornell, J. A. (1987). Response surfaces: design and analyses. Marcell Dekker Inc. New York.

Kim, J-H., Sunako, M., Ono, H., Murooka, Y., Fukusaki, E., and Yamashita. (2008). Characterization of gene encoding amylopullulanase from Plant-originated lactic acid bacterium, L.actobacillus plantarum L137. Journal of Bioscience and Bioengineering 106, 449459.

Md. Altaf., Naveena, B. J., Venkateshwar, M., Vijaya Kumar, E., and Reddy G. (2006). Single step fermentation of starch to $L(+)$ Lactic acid by Lactobacillus amylophilus GV6 in SSF using inexpensive nitrogen source to replace peptone and yeast extract-Optimisation by RSM, Process Biochemistry 41, 465-472.

Melasniemi, H. (1987). Characterization of $\alpha$-amylase and pullulanase activities of Clostridium thermohydrosulfuricum. Biochemical Journal 246, 193-197.

Miller, G. L. (1959). Use of dinitrosalicylic acid reagent for determination of reducing sugars. Analytical Chemistry 3, 426-428. 
Montgomery, D. C. (1991). Design and analysis of experiments. John Wiley and Sons Inc. New York.

Oh, S., Rheem, S., Sim, J., Kim, S. and Beak, Y. (1995). Optimizing conditions for the growth of Lactobacillus casei YIT 9018 in tryptone-yeast extract-glucose medium by using response surface methodology, Applied and Environmental Microbiology 61, 38093814.

Pan, C. M., Fan, Y. T., Xing, Y., Hou, H. W. and Zhang, M. C. (2008). Statistical optimization of process parameters on biohydrogen production from glucose by Clostridium sp. FanP2. Bioresource Technology 99, 3146-3154.

Pandey, A. (1992). Recent developments in solid state fermentation. Process Biochemistry 27, 109-117.

Pastrana, L. M., Gonzalez, M. P., Pintado, J. and Murado, M. A. (1995). Interactions affecting gibberellic acid production in solid - state culture: A factorial study. Enzyme and Microbial Technology 17, 784-790.

Plackett, R. L. and Burman, J. P. (1946). The design of optimum multifactorial experiments. Biometrika 33 , 305-325.

Rama Mohan Reddy, P., Gopal Reddy. and Seenayya, G. (1999a). Production of thermostable pullulanase by Clostridium thermosulfurogenes SV2 in solid state fermentation: Optimization of nutrients levels using response surface methodology. Bioprocess Engineering 21, 497-503.

Rama Mohan Reddy, P., Gopal Reddy. and Seenayya, G. (1999b). Production of thermostable $\beta$-amylase and pullulanase by Clostridium thermosulfurogenes SV2 in solid state fermentation: screening of nutrients using Plackett-Burman design. Bioprocess Engineering 21, 175-179.

Rama Mohan Reddy, P., Mrudula, S., Ramesh, B., Gopal Reddy. and Seenayya, G. (2000). Production of thermostable pullulanase by Clostridium thermosulfurogenes SV2 in solid state fermentation: Optimization of enzyme leaching conditions using response surface methodology. Bioprocess Engineering 23, 107-112.

Ramana Murthy, M. V. (1994). Fungal proteinase production by solid-state fermentation. Ph. D Thesis. CFTRI, Mysore, India.

Ramana Murthy, M. V., Mohan, E. V. S. and Sadhu Khan, A. K. (1999). Cyclosporin-A production by Tolypocladium inflatum using solid state fermentation. Process Biochemistry 34, 269-280.

Ramesh, M. V. and Lonsane, B. K. (1990). Critical importance of moisture content of the medium in $\alpha$ amylase by Bacillus licheniformis M27 in a solid-state fermentation system. Applied Microbiology and Biotechnology 33, 501-505.

Ramesh, M. V., Sergey, M. Podkovyrov., Susan, E. Lowe. and Zeikus, J. G. (1994). Cloning and sequencing of the Thermoanaerobaterium saccharolyticum B6A-RI apu gene and purification of the amylopullulanase from Escherichia coli. Applied and Environmental Microbiology 60, 94-104.
Reddy, L. V. A., Wee, Y-J., Yun, J-S. and Ryu, H-W. (2008). Optimization of alkaline protease production by batch culture of Bacillus sp. RKY3 through Plackett-Burman and response surface methodological approaches. Bioresource Technology 99, 2247-2249.

Saha, B. C., Jordan, D. B. and Bothast, R. H. (2009). Enzymes, Industrial (overview). Encyclopedia of Microbiology. In: Schaechter, M. (ed.). Elsevier, Oxford. pp. 281-294.,

Satyanarayana Naidu, G. and Panda, T. (1999). Performance of pectolytic enzymes during hydrolysis of pectic substances under assay conditions: a statistical approach, Enzyme and Microbial Technology 25, 116-124.

Sen, R. and Swaminathan, T. (1997). Application of response surface methodology to evaluate the optimum environmental conditions for the enhanced production of surfactin. Applied Microbiology and Biotechnology 47, 358-363.

Shen, G. J., Saha, B. C., Lee, Y. E., Bhatnagar, L. and Zeikus, J. G. (1988). Purification and characterization of a novel thermostable $\beta$-amylase from Clostridium thermosulfurogenes. Biochemical Journal 254, 835840.

Souza de O, M. C., Roberto, I. C. and Milagres, A. M. F. (1999). Solid - state fermentation for xylanase production by Thermoascus aurantiacus using response surface methodology. Applied Microbiology and Biotechnology 52, 768-772.

Son, K-H., Hong, S-H., Kwon, Y-K., Bae, K-S., Kim, YK., Kwon, B-M., Kim, S-U. and Bok, S-H. (1998). Production of a ras farnesyl protein transferase inhibiting from Bacillus licheniformis using PlackettBurman design. Biotechnology Letters 20, 149-151.

Spreinat, A. and Antranikian. (1990). Purification and properties of a thermostable pullulanase from Clostridium thermosulfurogenes EM1 which hydrolyses both $\alpha-1,6$ and $\alpha-1,4$ glycosidic linkages. Applied Microbiology and Biotechnology 33, 511-518.

Srinivas, M. R. S., Nagin Chand, and Lonsane, B. K. (1994). Use of Plackett-Burman design for rapid screening of several nitrogen sources, growth/product promoters, minerals and enzyme inducers for the production of alpha-galactosidase by Aspergillus niger MRSS 234 in solid state fermentation system. Bioprocess Engineering 10, 139-144.

Srivastava, R. A. K. and Baruah, J. N. (1986). Culture conditions for production of thermostable amylase by Bacillus stearothermophilus. Applied and Environmental Microbiology 52, 179-184.

Swamy, M. V., Sai Ram, M. and Seenayya, G. (1994). $\beta$ Amylase from Clostridium thermocellum SS8-A thermophilic, anaerobic, cellulolytic bacterium. Letters in Applied Microbiology 18, 301-304.

Swamy, M. V. and Seenayya, G. (1996a). Clostridium thermosulfurogenes SV9-A thermophilic amylases producer. Indian Journal of Microbiology 36, 181-184.

Swamy, M. V. and Seenayya, G. (1996b). Thermostable pullulanase and $\alpha$-amylase from Clostridium 
thermosulfurogenes SV9 - Optimization of culture conditions for enzymes production. Process Biochemistry 31, 157-162.

Venkata Rao, P., Kunthala Jayaraman. and Lakshmanan, C. M. (1993). Production of lipase by Candida rugosa in solid state fermentation. 2: Medium optimization and effect of aeration. Process Biochemistry 28, 391-395.

Vishnu, C., Naveena, B, J., Md Altaf., Venkateshwar, M. and Gopal Reddy (2006). Amylopullulanase - A novel enzyme of $L$. amylophilus GV6 in direct fermentation of starch to $L(+)$ lactic acid. Enzyme and Microbial Technology 38, 545-550.

Yu, X., Hallett, G., Sheppard, J. and Watson, A. K. (1997). Application of the Plackett-Burman experimental design to evaluate nutritional requirements for the production of Colletotrichum coccodes spores. Applied Microbiology and Biotechnology 47, 301-305.

Zarein, S., Khajeh, K., Ranjbar, B., Dabimanesh, B., Ghollasi, M. and Mollania, N. (2010). Purification and characterization of a novel amylopullulanase that converts pullulan to glucose, maltose, and maltotriose and starch to glucose and maltose. Enzyme and Microbial Technology 46, 57-63.

Zeikus, J. G. (1979). Thermophilic bacteria: Ecology, physiology and technology. Enzyme and Microbial Technology 1, 243-252. 